象であり症例を増やして質的診断へと期待したい。また ヒストグラム解析を行う場合に ROI の大きさの設定， どこを測るか，Gain 等の条件をよ゙うすべきか等の検討 すべきととがあり意見の統一の方向へ持っていくべきだ と考える。

以上まとめと私見を述べた。

\section{RI-6 試料測定一1}

座長 薄 英子 (三井記念病院)

\section{Ig-M 型 HBc 抗体 RIA kit の使用経験}

県立岐皋病院

○坂下英二・後藤 明

Ig-M 型 HBc 抗体測定 RIA kit について若干の基礎 的検討および，臨床評価を行った。

First Incubation 時間を変えた場合，許容時間内でほ ぼプラトーな值に達した。

希䣋倍率を変えた原合，様々に値が変化したが，てれ については，検体をもっと多く測定し，検討する必要が あると思われる，日差および同時再現性では，CV\%が 10\%内外となった. EIA との相関では，有意な相関が得 られた。急性B型肝炎の患者血清亡他の愚者血清（B刑 慢性肝炎・キャリア・非 $\mathrm{A}$ 非B型肝炎)について測定を 行った結果，急性 $\mathrm{B}$ 型肝炎では，カットオフインデック スが高く，他のものは低くなった。但し，慢性B型肝炎 の検体の中にも，陽性と判定されるものがあった。

332. 尿中アルドステロン測定方法に関する問題点 近畿大学医学部附属病院中央放射線部 ○辰已幸代・森田 修・山下筱雄

今回われわれは，尿中アルドステロン（aldo.）測定の 問題点につき検討を行い若干の知見を得たので報告した。 (1)防腐剤の種類および原尿 $\mathrm{pH}$ の違いによる影響はみ られなかった。(2)保存期間による影響では, $-20^{\circ} \mathrm{C}, 4$ ${ }^{\circ} \mathrm{C} ， 24^{\circ} \mathrm{C}$ ずれにおいても急激な低下がみられ，約 2 ケ 月後には最低值となった。 (3)凍結融解による影響では， 凍結回数が增すにつれ低值を示す傾问がみられた。 (4)加 水分解時間は約 20 時閪でプラトーとなり, また温度は室 温で最も高值が得られた。（5)加水分解後の稀釈液は $5 \%$ BSA および D.C.C. 処理を 2 度行った aldo. free 血清で 最す良好な結果が得られた。

抄録 Fig. 3 の凍結保存期間について，さらに短期間 のものにつき検討を行った。

333. RIA によるジギタリス剤迅速測定の成績 東邦大学大森病院 RI 空

○中込俊雄・小堺加智夫
- 浦慶和・ 丸儿雄三 東邦大学大橋病院 RI 室 星野光雄

われわれは，ファデバスジゴキシンりアキットを用い, 过速測定法における基礎的検討をし，本キットを用いて， デスラノシド, $\beta$ メメルシジキシン, ラナトサイドCを 測定する可能性を検討した。

インキュベーション時間を 3 〜30分まで変化させると 4.5〜70\%と Bo/T が増加したが，Bo/B は極く僅かな 增加しか示さなかった。 また精度と再現性は，C.V.で 3. 74〜7. 94 と 9. 89〜10.71であった. そして完全測定と の相関は0.97とよく相関した。しかし，迅速測定のため 測定内のインキュベーション時開誤差を 1 分以内にする 必要怔るう。 また，本キットはデスラノシド，ラナト サイドC， $\beta$ サチルジゴキシンと高い交叉反応を示した.

334. Radioimmunoassay による血中 free $T_{3}$ 測定につ いて

北海道社会保検中央病院放射線部 ○萩原康司・田回英雄・中島 詳

Immophase $\mathrm{FT}_{3}$ RIA kit ついて，測定法を主に検 討し，測定值を透析法と比較した。本法は 2 組の測定即 $5 \mathrm{FT}_{3}$ (A tube) と $\mathrm{TT}_{3}$ (B tube) を並行して行う. total $T_{3}$ 測定は， $T_{3}$ と TBG の結合阻害剂である ANS を加え， $\mathrm{FT}_{3}$ 測定には，乙れを加えない，測定法は，原 法通りで良いととを確認した。再現性では intra-assay precision $の \mathrm{CV}$ 值は 1.2 Ł. $0 \%$ ，一方 inter-assay では 12.4 亡 $10.9 \%$ 上良好であった。添加回收率試験では平均 93.4\%．血清稀䣋では，低および中濃度血清では原点を 通る直線となったが，高濃度血清では，曲線となった。 正常範国は，RIA 法 $(2.7 \sim 8.4 \mathrm{pmol} / \mathrm{L}) \cdot \mathrm{ED}$ 法 (2.7〜 $5.6 \mathrm{pmol} / \mathrm{L})$. RIA 法と ED 法の相関は， $\mathrm{y}=1.31 \mathrm{X}-$ 1. 66, $\mathrm{r}=0.928,(\mathrm{n}=232)$. 臨床的には, 低 $\mathrm{T}_{3} \mathrm{NTI}$ て RIA 法が低俻を示し，他は良好であった。

\section{MAGIC $T_{3}$ Uptake 測定法と臨床的検討}

北海道社会保險中央病院放射線部 RI 室

○四日英雄・中島 詳・萩原康司

本 kit は， B・F 分離法として $\mathrm{T}_{3}$ binder 液を使用し, $\mathrm{B} \cdot \mathrm{F}$ 分離に磁厅を用いている点で従来の方法にくらべ 極めてユニークである. 本法における受動係数は他の二 種類の $\mathrm{T}_{3} \mathrm{U}$ 測定法と比較しても決して大きくなく，磁 打を用いる B・F 分離法が極めて效果的であり再現性む 良好であるととを示している。測定条件のうち incubation 温度の影響はとりわけ重要で，単に窒温とするより， 一定温度は固定することが必要である。臨床的検討では， 